\title{
Influence of storage on the emission of volatile acids from wood chips
}

\author{
Einfluss der Hackschnitzellagerung auf die Abgabe von flüchtigen Säuren aus daraus hergestellten Spänen \\ und Fasern
}

E. Roffael • M. Uhde

Received: 5 April 2011 / Published online: 5 November 2011

(C) The Author(s) 2011. This article is published with open access at Springerlink.com

\begin{abstract}
Results of investigations on the influence of storage of wood chips from pine (Pinus sylvestris L.) and spruce (Picea abies Karst.) clearly showed that storage decreases the emission of volatile acids (formic and acetic acid). Moreover, it became obvious from the results that huge differences exist between pine and spruce in the emanation of volatile acids. The higher emission of formic acid from pine wood may be due to the much higher extractive content in pine wood compared to spruce as has been shown in a previous publication. Furthermore, the results reveal that thermomechanical pulping (TMP) of wood enhances, in general, the release of formic and acetic acid from wood. The release of volatile acids from TMP declines due to storage of wood. Storage also narrows the differences in the emission between pine and spruce wood particles and TMP prepared therefrom. It seems that there is some interrelation between the extractive content of wood and its change during storage on the one side and the release of volatile acids on the other side.
\end{abstract}

\section{Introduction}

Most woods, albeit not all, are acidic in nature and release different amounts of volatile acids depending on the prevailing boundary conditions. There is a spate of publications covering this subject (Packman 1960; Sandermann et al. 1970; Fengel and Wegener 1984; Roffael 1989). However, there is scarce knowledge regarding the influence of wood storage on the emission of volatile acids from different woods. Little is also known about the interrelation between

E. Roffael ( $\varangle) \cdot$ M. Uhde

Georg-August-Universität Göttingen, Göttingen, Germany

e-mail: eroffae1@gwdg.de the change in the chemical composition of wood during storage and the release of volatile acids thereof. Storage is a process of industrial interest which impacts the content and chemical composition of wood extractives and consequently the properties of wood and its suitability as a raw material for e.g. pulps and wood-based panels (Back and Allen 2000; Schäfer 1996). This paper aims, therefore, at assessing the impact of wood chip storage on the liberation of volatile acids. Moreover, one of the objectives was to evaluate the influence of storage on the release of volatile acids from thermo-mechanical pulps (TMP) made from wood chips stored for different periods of time.

\section{Experimental work}

Wood chips from pine (Pinus sylvestris L.) and spruce (Picea abies Karst.) cut in winter were stored over a period of 29 weeks in about $40 \mathrm{~m}^{3}$ piles. Samples of the chips were taken intermittently from the piles after 5, 12, 19 and 29 weeks. The chips were processed mechanically using a knife ring flaker to particles suitable for making particleboards. The particles were screened using a sifter and the fraction $\geq 0.5<1 \mathrm{~mm}$ was used to evaluate the emission of volatile acids after different storage periods. In another set of experiments the chips were thermo-mechanically pulped to fibres.

The release of volatile acids (formic and acetic acid) was determined using the flask method, as described in EN 717-3. The volatile acids in the absorbing medium (water) were estimated using the technique of ionic chromatography as described in an earlier publication (Roffael 1989). 
Fig. 1 Release of formic and acetic acid from unstored spruce and pine wood particles and after storage for 5, 12, 19 and 29 weeks, measured by the flask method (24 h-value) (according to the principles of EN 717-3) (n.d. = not determinable) Abb. 1 Abgabe von Ameisenund Essigsäure aus Spänen von ungelagertem und für 5, 12, 19 Fichten- und Kiefernholz, ermittelt mit Hilfe der Flaschenmethode (24 h-Wert) nach dem Prinzip der EN 717-3 (n.d. = nicht bestimmbar) und 29 Wochen gelagertem

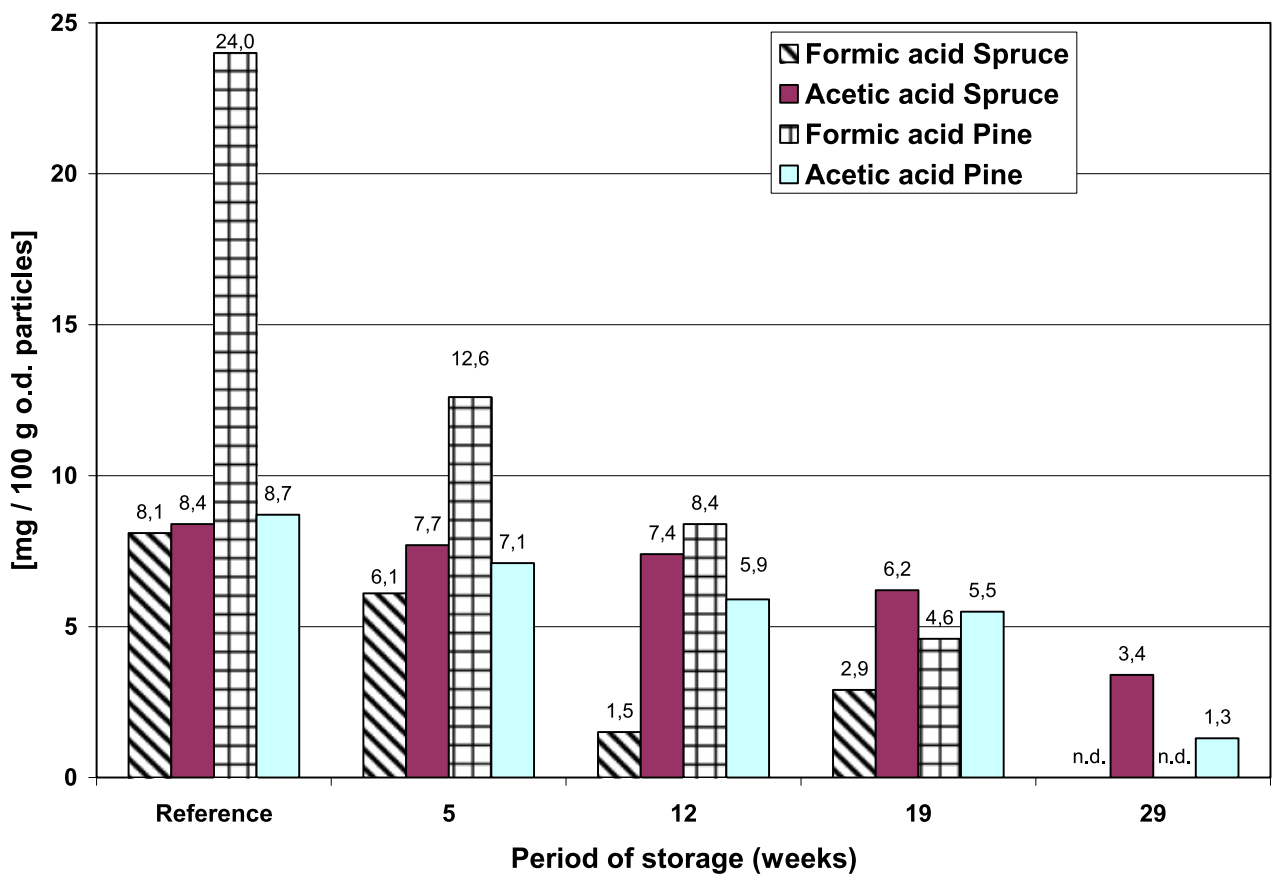

Fig. 2 Release of formic and acetic acid from spruce and pine wood TMP-fibres obtained from unstored wood and after storage for 5, 12, 19 and 29 weeks, measured by the flask method (24 h-value) (according to the principles of EN 717-3)

Abb. 2 Abgabe von Ameisenund Essigsäure aus TMP, hergestellt aus ungelagertem und für 5, 12, 19 und 29

Wochen gelagertem Fichtenund Kiefernholz, ermittelt mit Hilfe der Flaschenmethode ( 24 h-Wert) nach dem Prinzip der EN 717-3

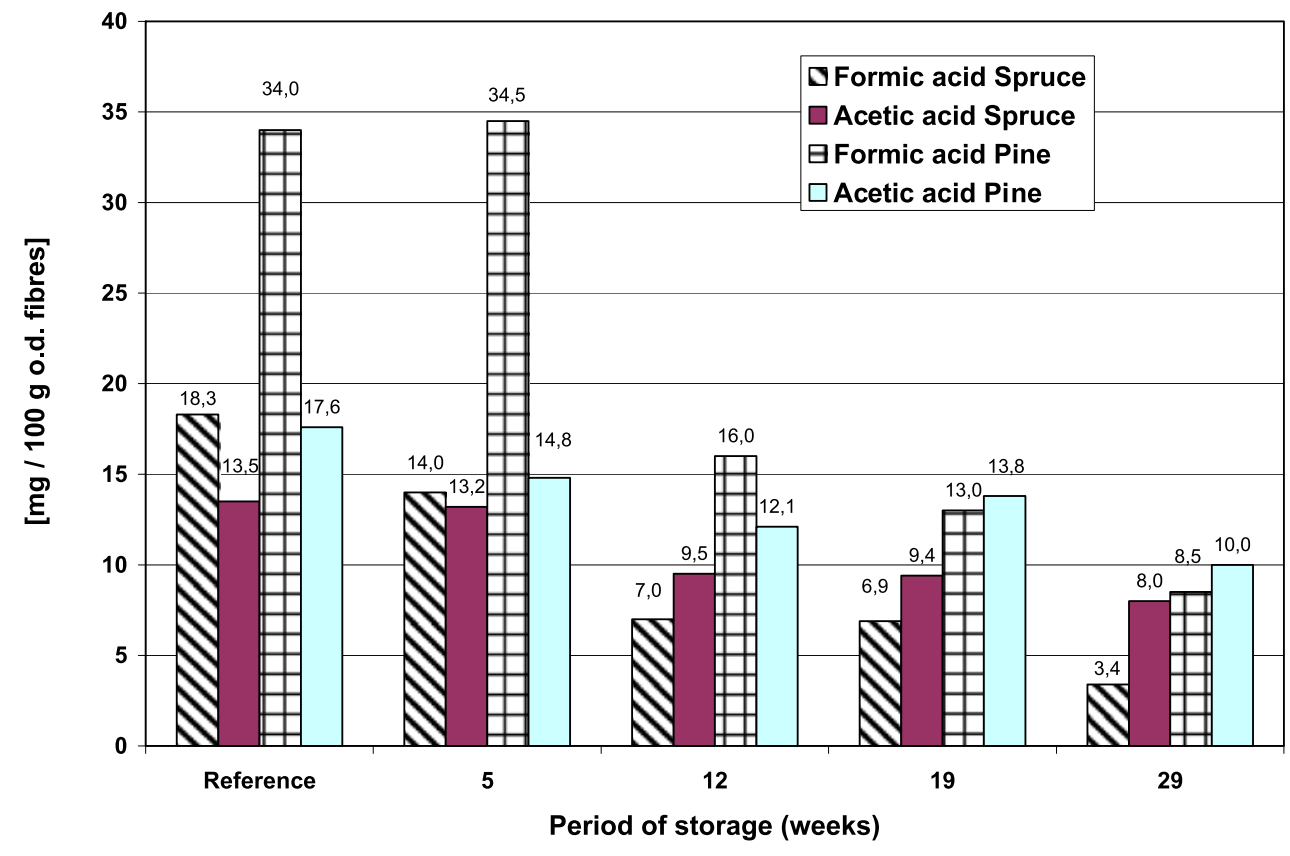

\section{Results and discussion}

As the results in Fig. 1 reveal, storage reduces excessively the emission of formic and acetic acids from pine and spruce wood particles. Evidently, particles from pine wood chips emit conspicuously higher amounts of formic acid compared to the spruce particles over a storage period of 19 weeks. Distinctive differences were particularly found in the early stages of storage. In case of acetic acid no huge differences were found over the whole storage period ( 29 weeks) between pine and spruce wood particles. The change in the extractive content due to storage has already been published (Roffael and Uhde 2011). To what extent changes in the extractive content and chemical composition of the extractives are involved in the process of emission of volatile acids, especially formic acid is still to be traced. The higher extractive content in pine wood could be accountable to the higher release of formic acid of pine wood compared to spruce wood.

In a foregoing publication, related to the influence of wood storage on the formaldehyde release, a noticeable decrease in the formaldehyde emission was established due to 
storage of pine and spruce wood over a period of 29 weeks (Roffael and Uhde 2011). As formaldehyde is oxidisable via a free radical mechanism to formic acid, even under ambient conditions (EU-Air pollution research report 10 1987), it becomes quite understandable that in the wake of such decrease also a decline in the release of formic acid follows. Insofar, oxidation processes seem to play a pivotal role during storage of wood.

Figure 2 shows the release of formic and acetic acid from thermo-mechanical pulps (TMP) made from wood chips after storage for different time intervals. Accordingly, TMP releases higher amounts of both acetic and formic acids than the wood particles themselves indicating that the TMPprocess enhances degradation of wood and the release of volatile acids thereof (Sohn and Lenel 1949). Again, horrendous differences were found in the emanation of formic acid between pine and spruce, which remain in hold even after 29 weeks of storage. Comparatively, small differences exist between spruce and pine wood in the emission of acetic acid as a function of storage time. As it becomes obvious from the results, storage leads to a remarkable decrease in the emission of both acetic and formic acids from the two investigated wood species. Moreover, storage narrows the differences in the release of formic acid between spruce and pine fibres.

It is noteworthy that no determinable amount of formic acid was released from wood particles after storage of wood chips for 29 weeks but from thermo-mechanical pulps (TMP) delivered thereof (see Figs. 1 and 2). This can be interpreted as a clear indication that during the thermohydrolytic treatment leading to TMP degradation of carbohy- drates in wood takes place inducing the formation of formic acid (Sohn and Lenel 1949; Schneider et al. 2004).

Open Access This article is distributed under the terms of the Creative Commons Attribution Noncommercial License which permits any noncommercial use, distribution, and reproduction in any medium, provided the original author(s) and source are credited.

\section{References}

Back E, Allen L (2000) Pitch control, wood resin and deresination. Tappi Press, New York. ISBN 0-89852-519-5

EU-Air pollution research report 10 (1987) Evaluation of atmospheric processes leading to acid deposition in Europe. Report on cost 611

Fengel D, Wegener G (1984) Wood. Chemistry, ultrastructure, reactions. de Gruyter, Berlin

Packman DF (1960) The acidity of wood. Holzforschung 14(6):178183

Roffael E (1989) Abgabe von flüchtigen organischen Säuren aus Holzspänen und Holzspanplatten. Holz Roh- Werkst 47:447-452

Roffael E, Uhde M (2011) Lagerung reduziert Formaldehydemission aus Spänen. Holz-Zentbl 137:272-273

Sandermann W, Gerhard U, Weißmann G (1970) Untersuchungen über flüchtige organische Säuren in einigen Holzarten. Holz RohWerkst 28:59-67

Schäfer M (1996) Einfluß der Lagerung von Fichten- und KiefernIndustrierestholz aus der Profilzerspanung auf die Eigenschaften von Spanplatten und mitteldichten Faserplatten (MDF). Dissertation, Georg-August-Universität Göttingen

Schneider T, Roffael E, Windeisen E, Wegener G (2004) Einfluss der Aufschlusstemperatur auf lösliche Kohlenhydrate bei der TMPHerstellung. Holz Roh-Werkst 62:321-322

Sohn AW, Lenel PO (1949) Über die Reaktionsprodukte einer schonenden partiellen Hydrolyse. Papier 3:109-118 